\title{
Author Correction: Coherent phase transfer for real-world twin-field quantum key distribution
}

\author{
Cecilia Clivati (1), Alice Meda (1), Simone Donadello (B), Salvatore Virzì (B), Marco Genovese, Filippo Levi,

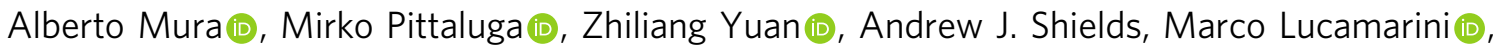 \\ Ivo Pietro Degiovanni \& \& Davide Calonico
}

Correction to: Nature Communications https://doi.org/10.1038/s41467-021-27808-1, published online 10 January 2022.

In this article, the funding from 'the project EMPIR 19NRM06 METISQ - this project received funding from the EMPIR program cofinanced by the Participating States and from the European Union Horizon 2020 research and innovation program.' was omitted. The original article has been corrected.

Published online: 04 February 2022

\begin{abstract}
(c) (i) Open Access This article is licensed under a Creative Commons Attribution 4.0 International License, which permits use, sharing, adaptation, distribution and reproduction in any medium or format, as long as you give appropriate credit to the original author(s) and the source, provide a link to the Creative Commons license, and indicate if changes were made. The images or other third party material in this article are included in the article's Creative Commons license, unless indicated otherwise in a credit line to the material. If material is not included in the article's Creative Commons license and your intended use is not permitted by statutory regulation or exceeds the permitted use, you will need to obtain permission directly from the copyright holder. To view a copy of this license, visit http://creativecommons.org/licenses/by/4.0/.
\end{abstract}

(c) The Author(s) 2022 